\title{
Neljännesvuosisadan jälkeen
}

Työväen Sivistysliiton liittotoimikunta on juuri myöntänyt minulle puolen vuoden palkallisen toimivapaan vuoden 1990 alusta voidakseni perehtyä erääseen kysymykseen, joka kiinnostaa minua ja jota pidän tärkeänä sekä sosialidemokraattisen työväenliikkeen että koko yhteiskunnan kannalta. Tietysti kysymys on myös ylimääräisestä palkkiosta minulle lähes neljännesvuosisadan palvelusta työväenliikkeen sivistystyöntekijänä ensin TSL:n opintojohtajana syksystä 1966, sitten SAK:n koulutussihteerinä vuoden 1971 alusta ja lopuksi TSL:n pääsihteerinä syksystä 1973 alkaen. Toimivapaan jälkeen en palaa TSL:n palvelukseen ainakaan pääsihteerinä, korkeintaan opintosihteerinä tai aineistotoimittajana. Olisi ehkä pitänyt siirtää tämän kirjoituksen tekemistä edes parilla kuukaudella, jotta olisin saanut vähän etäisyyttä työntäyteisiin vuosiini järjestöllisessä sivistystyössä. Toisaalta on kenties kiinnostavaa, minusta itsestänikin ehkä muutaman vuoden päästä, miten koen noiden 23 vuoden pohjalta järjestöllisen sivistystyön lähtöni jälkeen tuoreeltaan tulkittuna.

\section{Niin vähän tukijoita}

Päällimmäinen tuntemukseni tällä hetkellä on ilman muuta, että kovin harvassa ovat olleet järjestöllisen sivistystyön sivistyspoliittiset tukijat. ()pintokeskuslaki saatiin vuoden 1976 alusta. Se nosti sivistysjärjestön toiminnan määrällisesti uudelle tasolle ja antoi sysäyksen eräille uusille tulokkaille. Mutta pysähdys tuli jo 80luvun alussa, ja henkilökohtaisella tasolla siihen sisältyi tähänastisen elämäni suurin nöyryytys.

Hyvässä uskossa ja palvellakseni hyvin työväenliikettä olin harjoittanut TSL:ssä expansiivista henkilöstöpolitiikkaa ja lisännyt siten kiinteitä kustannuksia. Uskoin, että uudet vakanssit saadaan tuota pikaa valtionavun piiriin ja että toiminnallisella puolellakaan ei valtion tulo- ja menoarvio asettaisi esteitä. Toisin kävi. Vakansseja ei saatukaan valtionavun piiriin. Työväenliikkeen kurssitoiminta oli jatkuvasti edellä valtion tulo- ja menoarviossa varattuja määrärahoja. Tuloksena oli TSL:n talouden jonkinasteinen kriisi, joka maksuvalmiusongelmana on jatkunut tähän päivään saakka.

TSL:n liittotoimikunnan eräiden silloisten vaikutusvaltaisten jäsenten reaktio oli toimiston johtoon suunnatun kontrollin lisääminen, eikä sen sijaan tai edes sen lisäksi määrätietoiset sivistyspoliittiset toimenpiteet valtiovallan suuntaan. Se on jättänyt tähän päivään saakka ulottuvat jälkensä TSL:n hallinnon käyttäytymiseen.

En tiedä, olisiko TSL:n liittotoimikunnan niiden jäsenten, jotka edustivat sen poliittisesti vahvimpia jäsenjärjestöjä, aktiivinen sivistyspoliittinen toiminta tuonut parannusta TSL:n taloudelliseen asemaan. Joka tapauksessa minulle on jäänyt kokemuksestani vakaumus: Minkä tahansa yhteisön hallituksen jäsenen arvon olennainen mittari on, missä määrin häı haluaa ja kykenee hankkimaan yhteisölleen voimavaroja. TSL:n ja yleensä sivistysjärjestöjen tapauksessa aktiivisen ja taloudellisesti kestävän sivistyksellisen yhteistoiminnan luominen asiakkaan ominaisuudessa on yksi tapa. Mutta parhaimmillaankaan se ei korvaa lahjoitustuloja, parempaa valtionapua tai korkeampia jäsenmaksuja. Ne tuovat mahdollisuuksia kokeilemiseen, monipuolisuuteen, köyhien palvelemiseen ja riskinottoon, joita ilman sivistysjärjestöä uhkaa kaupallistuminen ja henkinen näivettyminen.

\section{Onko tuomittu nykyiselle tasolle?}

Kun järjestöllisen sivistystyön sivistyspoliittiset tukijat ulkopuolella sivistysjärjestöjen päätoimisen henkilöstön ovat olleet niin harvassa, on tietysti pakko kysyä, riittääkö suomalaiselle yhteiskunnalle järjestöllisen sivistystyön osalta se, mihin se työ nykyisellään yltää. On huomattava, että aikuiskasvatuspolitiikkasta vastaavat valtion viranomaiset ja suunnitteluelimet ovat 70-luvun lopulta lähtien suhtautuneet järjestöllisen sivistystyön suunnalta tulleisiin 
odotuksiin jollei suorastaan vihamielisesti niin ainakin välinpitämättömästi, sanoisinko kuin halpaan makkaraan. Yhtään sen myönteisempi ei ole ollut aikuiskasvatuksen tutkijoiden asennoituminen. Tiedossani ei ole yhtään tapausta, jossa joku heistä olisi ollut edes kiinnostunut kysymään, voidaanko järjestöllisen sivistystyön aseman vahvistamista puolustaa joillakin tosi painavilla argumenteilla.

Itse olen 70-luvun lopulta lähtien, jolloin TSL oli ensimmäisten joukossa jollei peräti ensimmäisenä rupeamassa tuomaan nykyistä kansanliikeasennoitumista suomalaiseen yhteiskuntaan, tullut yhä vakuuttuneemmaksi siitä, että vapaiden ihmisten vapaiden kansanliikkeiden vapaissa järjestöissä harjoitettu vapaa kansalaistoiminta on yhteiskunnan kansanvaltaisuudelle, toimivuudelle, kehittymiselle ja vetovoimaisuudelle korvaamattoman tärkeä. Tämä Alexis de Tocquevillen (1805-1859) ajoista elänyt teoria on mielestäni saanut voimakasta vahvistusta sosialististen yhteiskuntien ja lukuisten kehitysmaiden osoittamasta pysähtyneisyydestä ja siitä johtuneista vakavista ongelmista.

Sen sijaan en halua dogmaattisesti väittää, että kansanliikkeiden ja kansalaisjärjestöjen elinvoima edellyttäisi välttämättä vahvaa järjestöllistä sivistystyötä.

Voıdaanhan ajatella, että inmıset osaavat ja haluavat toimia järjestöissään ja kiinnittyä niihin ilman erityistä sivistyksellistä toiminnallisuutta. Eikö kansalaisten koulutustaso ole jatkuvasti noussut'

Haluan vain sanoa, että kovalle koetukselle kansalaisjärjestöt joutuvat vetovoimansa kanssa, jos aikuiset suhteellisesti yhä enenevässä määrin saavat sivistykselliset elämyksensä muissa yhteyksissä, konteksteissa, kuin järjestöllisissä. Työnantajien, valtion, kuntien ja kaupallisten yritysten sivistystarjonta on jatkuvasti lisääntymässä. Voiko se olla vaikuttamatta siihen, mitä asioita ja tässä tapauksessa erityisesti mitä toiminnallisia yhteyksiä ihmiset pitävät tärkeinä. Sen selvittämisessä olisi mielestäni aikuiskasvatuksen tutkijoillakin tärkeätä työkenttää.

\section{Tukea järjestölliselle kulttuuritoiminnalle}

Minulle on käynyt vuosien varrella niin, että olen ruvennut pitämään omaehtoista kulttuuritoimintaa tärkeämpänä kansalaisjärjestöille kuin opintotoimintaa. Järjestöllisen opintotoiminnan voi ainakin teoriassa korvata muualla hankittu osaaminen mutta järjestöllistä kulttuuritoimintaa ei teoriassakaan. Se johtuu asian luonteesta. Osaamisen oppiminen on yksi asia. Sen tavoitteellinen luova viljeleminen on toinen. Kansalaisjärjestön vetovoiman kannalta on jokseenkin samantekevää, missä mahdollisimman moni sen jäsen on oppinut ja edelleen oppii maalaamaan tauluja. Mutta sille on erittäin arvokasta, että sen sillä tavoin osaavat jäsenet voivat ja haluavat tulkita tuntojaan myös osana järjestönsä toimintaa ja jäsentensä elämää. Samoin on minkä tahansa osaamisen kohdalla. Olen aina pitänyt mahdollisimman syvällistä ideologista työtä tärkeänä jokaiselle kansanliikkeelle ja järjestölle. Kunnollisen ideologisen työn edellyttämää tietopohjaa ei ole mitenkään mahdollista ainakaan läheskään yksinomaan luoda järjestöllisessä opintotoiminnassa. Sen jälkeen jäsenten ideologinen luovuus on elinehto jokaiselle järjestölle vähänkin pitemmällä tähtäyksellä.

Edellä sanomani ei tietenkään ole suunnattu järjestöllistä opintotoimintaa vastaan. Luulenpa, että samalla panostuksella kuin minkä kansalaisopistot nykyisin saavat valtiolta ja kunnilta, se saavuttaisi monelta osin parempia tuloksia kuin ne. Haluan järjestöllisen kulttuuritoiminnan merkityksen korostamisellani osoittaa, miten vajavainen ja väärin painottunut järjestöllisen sivistystyön valtionapujärjestelmä nykyisellään on.

\section{Luotettavuuden takaaminen}

Valtion on edellyttänyt aikamoista valvontahallintoa voidakseen olla varma, että järjestölliseen sivistystyöhön osoitetut varat käytetään myönnettyihin tarkoituksiin. En minä ole koskaan pitänyt sitä minään valtiollistumisena. Olen ymmärtänyt valtion tarpeen. Olen pitänyt sitä jopa hyvänä sen takia, että luotettavuus valtion varojen käytössä on tehnyt mahdolliseksi jakaa ahaa toiminnan määrän mukaan. On voitu torjua könttäsummaperiaate, joka olisi hyvin äkkiä joutanut parlamentaaristen voimasuhteiden noudattamiseen, joka puolestaan olisi johtanut asian viereen.

Järjestöllisen sivistystyön valvontahallinnossa ei vain vieläkään ole päästy eroon laitosmaisesta ajattelusta opintokeskusten osalta. Opintokeskukset samaistetaan opistoihin, joiden toiminta tapahtuu samojen ulkoseinien sisällä tai ainakin yhden kiinteistön alueella.

Opintokeskusten toiminta tapahtuu koko maassa ja on määrällisesti aivan toista luokkaa kuin opistojen. Sen takia pitäisi taas kertaalleen miettiä, mitkä paperit ja mitkä tiedot eri papereissa ovat todella tarpeen. Itse olen aina edustanut ajattelua: kevyt paperihallinto ja todellinen pistokoetarkastusten uhka.

Minun tietääkseni eivät osanottajat ja asiakkaat osallistu missään vapaan sivistystyön muodossa puhumattakaan muusta aikuiskasvatuksesta läheskään siinä määrin hallinnollis- 
ten toimenpiteiden suorittamiseen kuin järjestöllisessä sivistystyössä. Yhdistys, joka aikoo harjoittaa kurssitoimintaa, saa olla kiitollinen, jos joku sen jäsenistä ottaa vastuulleen paperisodan. Järjestöllisen sivistystyön valtionapu on jäänyt pahasti liian pieneksi, kun sivistysjärjestöt opintokeskuksineen eivät ole kyenneet vapauttamaan asiakkaitaan hallintohuolista.

Järjestöllisen sivistystyön valtionapuhallinnon kehittämisessä on kaksi mahdollisuutta. Joko annetaan sivistysjärjestöille lisää voimavaroja hallinnon hoitamiseen asiakkaidensa puolesta, tai ryhdytään aidon luoviksi hallintopaperien, tietojen ja toimenpiteiden radikaaliseksi vähentämiseksi.

\section{Jäykistävätkö sivistysjärjestöt rakenteen?}

Suomessa on tällä hetkellä yksitoista opintokeskusta ylläpitävää sivistysjärjestöä. Niiden kautta kanavoituu valtion tuki järjestölliselle sivistystyölle. Niiden jäseninä on muutama sata valtakunnallista järjestöä, joukossa luultavasti kaikkein suurimmat. Paljon järjestöjä on ulkopuolella, mutta nekin saavat osakseen niin halutessaan sivistysjärjestöjen palveluja.

Yhtä poikkeusta lukuunottamatta kuuluvat sivistysjärjestöt jäsenjärjestöineen jokainen omaan kansanliikkeeseensä. Poikkeuksella, Opintotoiminnan Keskusliitolla, on varsin heterogeeninen järjestöpohja. Teoria onkin, että sivistysjärjestö tukee sivistyksellisin keinoin kansanliikkeensä säilymistä ja kehittymistä kansanvaltaisena ja vetovoimaisena. Vaikeata olisikin ajatella, että sivistysjärjestöt olisivat vain neuvonta- ja rahanjakokeskuksia jäsenjärjestöilleen sitoutumatta niiden pyrkimyksiin ja pyrkimättä olemaan niille yhdistävä tekijä. Toisaalta politiikka on ollut, että opintokeskuksen ylläpito-oikeuksia on ikäänkuin luvattu antaa mahdollisille uusille sivistysjärjestöille hyvin niukasti. Kaikille tuli yllätyksenä Demokraatti- sen Sivistysliiton saama oikeus opintokeskukseen. Asian takana uumoiltiin olevan jonkin poliittisen lehmänkaupan.

On syytä kysyä, jäykistääkö kerran syntynyt sivistysjärjestöjen ja niiden opintokeskusten verkko yhteiskunnan kansanliike- ja kansalaisjärjestörakenteen. Saavatko siinä verkossa jo mukana olevat liikkeet ja järjestöt niin merkittävän kilpailuedun uusiin tai muusta syystä ulkopuolisiin nähden, että ne voivat ehkäistä jälkimmäisten voimistumisen niiden vakaviksi haastajiksi.

Vihreillä ei ole omaa sivistysjärjestöään, vaikka heidän aitouttaan kansanliikkeenä tuskin kukaan kiistää. Sen puuttuminen on ehkä heidän oma vikansa. Mutta onko heidän kannattanut sitä perustaakaan, jos sille ei kuitenkaan olisi ollut luvassa opintokeskuksen ylläpito-oikeuksia. Itseäni kysymys kiinnostaa humanistiliikkeen kannalta. Suomessa on kolme valtakunnallista järjestöä, Suomen Humanistiliitto, Vapaa-ajattelijain liitto ja Skepsis ry, joiden jo moni ja päivä päivältä yhä useampi niiden jäsen kokee kuuluvan yhteen maailmankatsomukselliseen liikkeeseen, kansainväliseen humanistiliikkeeseen. Jos ne ja mahdollisesti yhdessä niiden kanssa jotkin muutkin samanhenkiset järjestöt ja muut yhteisöt perustaisivat Humanistisen Sivistysliiton, joka hakisi opintokeskuksen yltäpito-oikeutta valtioneuvostolta. Saisiko se sen? Kuinka paljon sen jäsenjärjestöillä pitäisi olla jäseniä, jotta se sen saisi?

Valtion ei politiikallaan pitäisi suosia yksiä kansanliikkeitä toisten kustannuksella. Sen pitäisi vain osaltaan luoda mahdollisimman hyvät edellytykset kansanliikkeiden syntymiselle ja kehittymiselle. Luulen, että Suomen sivistyspolitiikassa joudutaan hyvinkin pian omaksumaan tähänastista liberaalimpi linja sivistysjärjestöjen tunnustamisessa valtionapukelpoisiksi esimerkiksi opintokeskuksen ylläpito-oikeus myöntämällä. Demokraattisen Sivistysliiton tapaus on siitä enne. 